Valerie Martin, Céline Le Bourdais \& Évelyne Lapierre-Adamcyk

\title{
Stepfamily instability in Canada - The impact of family composition and union type
}

\section{Instabilität von Stieffamilien in Kanada: der Einfluss der Familienkonstellation und der Art der Partnerschaft}

\begin{abstract}
:
The aim of this paper is to analyze stepfamily instability in Canada by applying the proportional hazards model to the information collected in the 2001 General Social Survey on Family. More specifically, we examine the effect that the family composition and the type of conjugal union exert on the risk of separation, and test whether the impact of cohabiting union varies over time and between Quebec and the other provinces, depending of its stage of institutionalization. The analysis shows that stepmother families face a lower risk of separation than those formed around a stepfather, and that cohabiting stepfamily couples are more unstable than married ones. The risk of union dissolution among stepfamily couples has increased over time, for married as well as cohabiting partners, but the effect of cohabitation relative to marriage does not appear to significantly differ across periods or regions.
\end{abstract}

Key words: stepfamily instability, family composition, type of union, event history analysis, women, Canada

\begin{abstract}
Zusammenfassung:
Der vorliegende Artikel untersucht die (In)stabilität von Stieffamilien in Kanada. Die Analysen wurden mit dem General Social Survey (GSS) 2001 unter Anwendung der Ereignisdatenanalyse durchgeführt. Von besonderem Interesse waren der Einfluss der Familienkonstellation und die Art der Partnerschaft auf das Trennungsrisiko. Ferner wurde untersucht, wie sich die (In)stabilität von Stieffamilien über die Zeit entwickelt hat. In der kanadischen Provinz Québec gelten nichteheliche Lebensgemeinschaften bereits als vollständig institutionalisiert. Ein weiterer Aspekt dieser Studie war der Vergleich der Entwicklung der québecer Stieffamilien mit denen im restlichen Kanada über die Zeit. Die Ergebnisse zeigen, dass Stiefmutterfamilien ein geringeres Trennnungsrisiko haben als Stiefvaterfamilien und dass Ehen in Stieffamilien stabiler sind als in nichteheliche Lebensgemeinschaften. Ebenso konnte gezeigt werden, dass für beide Partnerschaftstypen das Trennungsrisiko über die Zeit hinweg stark zugenommen hat.
\end{abstract}

Schlagwörter: Stieffamilieninstabilität, Familienkonstellation, Art der Partnerschaft, Ereignisdatenanalyse, Frauen, Kanada 


\section{Introduction}

In Canada, as in most western countries, the past several decades have been characterized by high levels of conjugal instability. Following the adoption of the Divorce Law by the Canadian Parliament in 1968, the proportion of marriages ending in divorce doubled from less than $20 \%$ in 1970 to approximately $40 \%$ at the end of the 1980 s, and has fluctuated around this level thereafter (Le Bourdais/Lapierre-Adamcyk 2004). The increase observed is due to the higher propensity of couples to separate and their tendency, over time, to do so at shorter durations of marriage, even in the presence of young children.

Marriage has not only become more unstable, it is also progressively being replaced by cohabitation, first, as a way to enter conjugal life and, more recently, as a conjugal setting in which to have and raise children. Recent data show that only half of Canadian women would marry at least once in their life if the trends observed were to continue (Le Bourdais/Lapierre-Adamcyk 2004). By the turn of the century, over $40 \%$ of young Canadians started their conjugal life through cohabitation rather than marriage (Statistics Canada 2002a) and slightly over $20 \%$ of children were born to cohabiting parents (Juby et al. 2005b). Cohabiting unions in which children are born tend to last longer than those that are childless, but they still remain significantly more unstable than marriages (Bumpass/Lu 2000; Le Bourdais/Juby 2002). The number of children who see their parents separate has thus increased substantially over the years.

Following the breakdown of their first family, a substantial proportion of men and women start living with a new partner, most often through cohabitation the second time around. They then form a stepfamily, that is, a family that comprises at least one child born from one of the two partners' prior relationship. With the prevailing level of conjugal instability, the number of stepfamilies has increased over the years. In 2001 in Canada, these families represented $10 \%$ of all families (and 12\% of two-parent families) with children under the age of 21 (Lapierre-Adamcyk/Le Bourdais 2008). This percentage compares to that observed in the US and most European countries (Sweeney 2010).

Several studies conducted in the 1980s and 1990s have analysed union instability in remarried families and stepfamilies. They found these families to be more unstable than first married families (Teachman 1986; Wineberg 1992) and concluded that the complexity of the family structure was one of the main factors associated with union dissolution (Cherlin/Furstenberg 1994). However, as argued by Coleman et al. (2000) who conducted an extensive review of research on remarriage, these studies suffered from a number of methodological and conceptual drawbacks, namely the lack of attention they gave to stepfamily diversity by excluding, for example, cohabiting stepfamilies, and their tendency to rely on cross-sectional data that are inadequate to capture the dynamic nature of the ongoing processes. Since the turn of the century, a large body of psycho-sociological research has focussed on the nature and quality of the relationships existing among the various members that belong to a stepfamily. A number of demographic studies have analysed childbearing within stepfamilies and examined whether the number of children from previous unions affect the likelihood of having a common biological child with a new partner (Sweeney 2010). However, in spite of the impact it has on the life of individuals, the study of stepfamily instability per se has been neglected by researchers (for an exception, see Teachman 2008). 
In Canada, the last demographic study to our knowledge that analysed stepfamily instability used the 1990 General Social Survey (GSS) on family. In line with previous research, this study showed that the composition of the family (stepfather or stepmother) and the type of the union (marriage or cohabitation) were important determinants of its duration (Desrosiers et al. 1995). In the ten years following that survey, several changes that have possibly modified the effects of these two variables on stepfamily instability have occurred. On one hand, the popularity of cohabiting unions has continued to grow, especially among stepfamily couples who, by 2001, in majority were living in this type of union (Lapierre-Adamcyk/Le Bourdais 2008), and more so in the province of Quebec, where it reached a level similar to that observed in the Scandinavian countries (Statistics Canada 2002b). On the other hand, the composition of stepfamilies has become more diversified, with courts less likely to grant women the sole custody of their children following parental separation. Consequently, one might ask whether the composition of the family and the type of the conjugal union still constitute strong determinants of the likelihood of separation among stepfamilies. Do the stepfamilies formed during the 1990s differ from those formed earlier in their likelihood to break up? Has the negative impact of cohabitation on stepfamily duration diminished over time, as cohabiting unions became more widespread and socially acceptable, and is its impact likely to be lower in Quebec, where this form of union is more common than elsewhere in Canada? These questions constitute the main focus of this paper that uses the 2001 Canadian GSS on family.

\section{Previous literature and research hypotheses}

The high rate of union dissolution in remarried stepfamilies has been well documented in past research (Cherlin 1978; White/Booth 1985; Teachman 1986; Clarke/Wilson 1994; Bumpass/Riley 2007, cited in Sweeney 2010). These families present particular characteristics and histories that appear to be related to the high level of family break-ups observed. Hence, at least one of the partners has already experienced a marital disruption. While one could expect separated individuals to have learned from their previous relationships and to be more settled and more inclined to resolve conflicts, and consequently to face lower risk of marital breakdown, past research has repetitively shown that remarried couples are less stable than first married ones. Some authors have argued that the high level of instability observed among stepfamilies is linked to the fact that remarried partners are more likely to be "poor marriage material" (Booth/Edwards 1992:181), that is, to comprise individuals who have difficult personalities, poor communication skills and present drug use or alcohol abuse problems. Now that divorce has become relatively common, it seems somewhat inappropriate to attribute the high rate of second union disruption mostly to individuals' psychological problems, even though such problems certainly do play a role in the break-up of some relationships. Rising aspirations of self-fulfilment and individuation are doubtlessly linked to individuals' willingness to break up or leave unhappy relationships (for a discussion, see Beck/Beck-Gernsheim 2002; Giddens 1992). The values and attitudes held towards marriage and divorce have profoundly changed over time (Van de Kaa 1987). Individuals entering a second marriage know that divorce is a possible and accepted solution and they might thus be more prone to see it as a way to end an unhappy marriage. 
In a well-cited article, Cherlin (1978) also invoked the lack of institutionalization of remarriages to account for their increased fragility. He argued that the lack of clear norms defining (step)parent and (step)child relationships leads to role ambiguity that, in turn, can result in conflicting situations among stepfamily members who had experienced different family histories. In a more recent article, Cherlin (2004) argued that, contrary to his earlier expectations, stepfamily life has not become more institutionalized but is rather now guided by weakened behavioural norms, due to the deinstitutionalization of marriage itself and the rise of cohabitation.

\section{Stepfamily composition and the risk of family disruption}

Stepfamilies can take various forms and configurations. No common definition of what constitutes a 'stepfamily' can be found in the literature, and the terms used to describe the diverse arrangements that stepfamilies take vary across studies (for a discussion, see Martin/Le Bourdais 2008). Here, we adopt an inclusive definition and consider as a stepfamily any couple living together with at least one child who is not the biological or adopted child of both partners ${ }^{1}$. Contrary to most research conducted previously in the US (for exceptions, see Bumpass et al. 1995; Stewart, 2001), we do not restrict our definition to remarried couples and include cohabiting couples whose number has been steadily increasing over time. We also take into account the families formed by women, following the birth of children outside a union with a partner who is not the father of these children, which have rarely been included in past stepfamily research (for exceptions, see Henz/Thomson 2005; Stewart 2007). To distinguish the various configurations that stepfamilies can take depending upon the origin of the children living with the couple, we use the terms 'stepfather family' and 'stepmother family'.

The family composition is one of the main characteristics that have been taken into consideration in past studies focussing on stepfamilies. Psychological research has predominantly used this variable to assess the quality of the relationships existing between stepparents and stepchildren, while socio-demographic research mostly brought it into play to account for the differential levels of union dissolution observed across stepfamilies. Both fields of research have produced a series of findings which are not easily reconcilable regarding the type of relationship that might be more conducive to stepfamily stability.

Most research based on clinical or psychological studies reports that stepmothers experience more difficulties than stepfathers in their relationships with their partner's children (Ambert 1986; Pasley/Ihinger-Tallman 1987; Ihinger-Tallman/Pasley 1997). The difficulties they face in adjusting to their stepparent role would contribute to lower conjugal satisfaction and thus increase the risk of separation among this type of family (Cherlin/Furstenberg 1994; Coleman et al. 2000). Several explanations have been advanced to account for this finding. First, Ihinger-Tallman (1988) suggests that children living in stepmother families might experience conflicting loyalty feelings between the stepmother who recently entered their life and their own mother with whom they are likely to maintain regular contact. Recent research also suggests that stepmothers face difficulties in their relationships with stepchildren given the powerful stereotypes of the nurturing

1 Excluding foster children. 
mother and the "wicked" stepmother that exist (Sweeney 2010: 676). Ambert (1986) further hypothesizes that stepmothers' negative perception of their role is probably linked to the fact that most of them do not live on a regular basis with their stepchildren. As a consequence, they are unable to develop a warm and secure relationship with their stepchildren as those with live-in stepchildren might achieve, while they still have to cope with the additional household work incurred by their visit.

Fatherhood has not in the past been as firmly associated as motherhood with child rearing, and expectations towards stepfathers have remained relatively modest (IhingerTalman 1988). Compared to biological fathers, stepfathers are not expected to play a very active role in taking on the care and the responsibility of children (Fine 1995), and they are more likely to adopt a "disengaged style of stepparenting" (Ihinger-Talman/Pasley 1997:22). Consequently, they tend to report relatively high levels of satisfaction with their parental role when they succeed in developing a good friendship relation with the children and are able to support their partner - the biological mother of these children -, in order to decrease her financial hardship or make it possible for her to work outside the home. Cherlin and Furstenberg (1994) also mention that stepparenting is often easier for men than women, since stepfathers often occupy a place that has been left empty after the departure of the biological father, whereas stepmothers often have to compete with the biological mother for gaining the children's affection.

While psychological studies all concluded that the role of stepfather might be easier than that of stepmother and thus suggested that stepfather families are perhaps more stable than stepmother families, demographic research has unequivocally shown that the former are more at risk of breaking up than the latter (Desrosiers et al. 1995; Juby et al. 2001; Teachman 1986, 2008). The main argument advanced in the literature to account for this finding is based on the assumption that stepmothers are more willing than stepfathers to invest into the relationship with the children, thus making these families more stable. Another explanation could well reside in the role tensions that mothers in stepfamilies experience as they feel "caught in the middle", that is, between their children and new conjugal partner. When conflicts develop between children and stepfathers, mothers' loyalties generally lay with the former, at the risk of jeopardizing their conjugal relationship (Weaver/Coleman, 2010). Another research suggests that stepmother families are more likely to be families in which the biological father is deeply involved in child rearing, as exemplified by the fact that he has custody of his children; these men are expected to be highly committed to family life in general and to invest into the relationship with their partner - the stepmother -, thus making the family more stable (Juby et al. 2005a).

Following the results of demographic studies, we expect stepmother families to be less at risk of breaking up than stepfather families.

The existence of a previous union - Whether the stepfamily was formed after the break-up of a two-parent family or following the birth of a child outside a union is another characteristic that is likely to affect the stability of the family. A non negligible fraction of the stepfather families are formed by lone mothers who gave birth to children outside of a union (Juby et al. 2001); in contrast, stepmother families very rarely include a biological father who did not previously live in a union (Ermisch/Wright 1991).

Stepfather families formed by mothers who did not live with the biological father of their children are expected to be more stable than those who lived together until separation. 
In the latter case, the children and the mother who went through the process of separation might find difficult the adaptation to a stepfather who did not share their previous family experience, while the stepfather might find it hard to develop a positive relationship with children in the presence of an actively involved biological father (Cherlin/Furstenberg 1994). In the former case, children might welcome the attention they get from a fatherly figure, especially if their father never lived with them and was totally absent from their life. Single mothers might also appreciate the support they receive from their new partner in taking care of their children, and his financial contribution to the household, given the economic difficulties that many of them faced (McLanahan et al. 2003).

Consequently, we expect the stepfather families in which women had no prior union to be less at risk of experiencing a separation than those formed after union dissolution.

\section{Type of union and the risk of family disruption}

Cohabiting unions have become relatively widespread in Canada, especially in Quebec where $30 \%$ of couples reported living together outside of marriage in 2001 (Statistics Canada 2002b). This conjugal arrangement is even more frequent among stepfamilies, with couples increasingly choosing to cohabit rather than remarry following marital dissolution. A quarter of stepparents were cohabiting in the U.S. in the late 1980s (Bumpass et al. 1995) and half of Canadian stepfamilies, and as much as $70 \%$ of those living in Quebec, were doing so in 2001 (Lapierre-Adamcyk/Le Bourdais 2008).

Non-marital unions are less stable than marriages (Wu 2000). They are less institutionalized and they require less formal commitment than marriages; their boundaries are more flexible, and finalizing separation is easier to achieve than it is for married couples (Cherlin 2004). Manning and Lamb (2003) further argue that, in the U.S., cohabiting couples have less legal and social recognition than married couples, and that the obligations and rights of cohabiting stepparents towards children may be unclear and a source of conflict. Compared to their married counterparts, cohabiting stepfamilies would face a "particularly pronounced" incomplete institutionalized status (Sweeney 2010: 671), which could lead to increased levels of tension and higher risk of union instability.

Consequently, we expect stepfamily couples living in a cohabiting union to be less stable than those who are married.

The degree of instability of cohabiting unions has, however, been shown to vary across countries, depending on the relative number and achieved level of institutionalization of these unions in each country. In Sweden, for instance, where non-marital unions are widespread and have almost replaced marriage as a way to have and raise a family, cohabiting couples benefit from similar rights to those of married couples in many areas of life, and have been found to be relatively more stable than in countries in which they are less prevalent (Kiernan 2002). Similarly, past research has shown that, as the number of cohabiting unions increased, the gap in the level of instability observed between Canadian two-parent families formed through cohabitation or marriage has diminished, especially in the province of Quebec, where cohabitation has achieved a higher stage of development than elsewhere in Canada (Le Bourdais/Juby 2002). 
Based on these results, we further posit that the negative impact of cohabitation on stepfamily relative to that of marriage will decrease over time, as cohabitation becomes more widespread. We also expect the difference separating Quebec cohabiting and married stepfamily couples to be smaller than it is outside of Quebec; in other words, when compared to their married counterparts, cohabiting stepfamily couples should be relatively less likely to separate in Quebec than they are elsewhere in Canada.

\section{Other independent variables}

The birth of a child - The birth of a child in a stepfamily is not an uncommon event. Indeed, a recent Canadian study found that close to $40 \%$ of stepfamilies comprise at least one child born during the course of the union, a child who is the half-brother or sister of the children already present in the family (Lapierre-Adamcyk/Le Bourdais, 2008). As in first married families, the birth of a child has generally been shown to be positively associated with union stability (Desrosiers et al. 1995; Teachman 1986) even though, as Wineberg (1992: 880) argued, the arrival of a new child adds "further complexity in an already complex system". One of the explanations advanced for the stabilizing influence of childbearing in stepfamilies is that the new child genetically links all members of the stepfamily to one another, thus reinforcing emotional ties between them (Juby et al. 2001), and leads to increased family solidarity by legitimating in their parental role the men or women who, prior to the birth of the common child, were only involved as stepparents with children (Ambert 1986).

Other control variables - In addition to the above variables, our analysis also includes the age of partners, which is generally negatively associated with union instability. We also control for the age and number of children who belong to the stepfamily, as previous studies have shown that adolescents might have more difficulties than younger children in accepting living with a stepparent (Ihinger-Tallman 1988; Hetherington 1993; Pasley/ Moorefield 2004). The period during which the stepfamily episode was experienced is included in our models in order to control for changing conjugal patterns. Finally, we also take into account respondents' mother tongue, religious affiliation, highest level of education achieved, and work status throughout the stepfamily episode, as these variables have all been found to be linked to conjugal instability in Canadian studies (Hall/Zhao 1995).

\section{Data and methods}

Data - Our analysis is based on the General Social Survey (GSS) on Family conducted by Statistics Canada in 2001. The GSS interviewed a large sample of approximately 24,000 adult men and women, representative of the Canadian population aged 15 years and older living in private households (Statistics Canada 2001). ${ }^{2}$ In addition to gathering detailed information on respondents' individual and household characteristics at the time of the survey, the GSS collected their retrospective education and work histories. Respondents were

2 Excluding the residents of Yukon, the Northwest Territories and Nunavut. 
also asked to record the history of all the unions (marriages or cohabiting unions) they had experienced and of all the children they had given birth to, adopted and/or raised. For each union reported, the GSS gathered the date of beginning and, if applicable, the date and reason of ending of the union. ${ }^{3}$ For each child, the GSS collected the date of birth, as well as the date of arrival in the respondent's household of adopted and step-children; the date at which each child left the household for the last time was also recorded. Only female respondents are retained for the analysis, in order to avoid report biases linked to men's conjugal and parental histories (Rendall et al. 1999; Juby/Le Bourdais 1999).

Constructing the stepfamily episodes - By combining the information collected in the conjugal and parental histories, we were able to reconstruct all the stepfamily episodes that women had experienced prior to the survey. The episodes are set to begin from the moment a woman starts living with a married or cohabiting partner, and with children who are not the biological or adoptive children of both partners. They can end in three different ways: when the union breaks up, with the death of the partner, or when the last stepchild who lives in the family leaves the parental home.

The pathways to stepfamily formation are quite diverse. Each partner might have joined the stepfamily without having first experienced a previous union or following the dissolution (separation or death of partner) of a marriage or of a common-law relationship. Moreover, each episode might include children born from a previous relationship (within or outside a union) of one or the two members of the couple. Unfortunately, the GSS did not collect any information on the parental histories of women's partners. It is therefore impossible to determine with certainty whether the partner who started living with a woman who gave birth outside a union is the biological father of the child. Here, we consider that children born up to six months prior to the beginning of a union belong to the union or, in other words, that they are the biological children of the couple; in such cases, the family unit is therefore not counted as a stepfamily. ${ }^{4}$ The lack of information on the partners' parental histories also makes it impossible to identify non-resident stepmothers in our sample, that is, women who did not mention having raised and lived with their partner's children. ${ }^{5}$ Consequently, our study includes only resident stepparents and excludes those who never lived with their stepchildren. Finally, one should note that the GSS did not gather information on children's living arrangements, which might have changed over the course of the episode as the amount of time they spent in each of their separated parents' household fluctuated. We only know the date that children arrived in the respondents' life through birth, adoption or as stepchildren, as well as the date of their

3 The GSS collected the date (month and year) of each event, but the microdata file created by Statistics Canada provides the age (with a decimal) of respondents at each event.

4 The cut-off point retained to determine whether children born before the beginning of a union belong to this union or not varies across studies, from 0 month, in Prskawetz et al.'s (2002) research that treated as stepchildren all children born prior to the union, to 6 months (Griffith et al. 1985; Desrosiers et al. 1995) and even 11 or 12 months (Buber/Prskawetz 2000; Thomson 2004). We ran separate analyses using a 12-month cut-off point and found no changes in the results. We thus used 6 months as our cut-off point, as was done in a previous Canadian study (Desrosiers et al. 1995).

5 Respondents were first asked if they had "ever raised step-children". If so, they were further asked "in what month and year" did each step-child "join their household" and, if applicable, "in what month and year" he or she "last left home". 
last departure from home; we are thus forced to assume that children are living in the respondent's home until this last date. ${ }^{6}$

Our analysis includes solely the first stepfamily episodes reported by women, which constitute the large majority of episodes spent in this type of family. ${ }^{7}$ The sample first comprised 1,511 female respondents who had experienced at least one episode of stepfamily life in adulthood at the time they were reached by the survey (for more details about the constitution of the sample of stepfamily episodes, see the Appendix). We excluded from the analysis 158 episodes that comprised only children aged 21 years or older at the formation of the stepfamily. ${ }^{8}$ The final analytical sample comprises 1,353 female respondents who spent at least some time in a stepfamily household.

Method - We use Cox proportional hazard models to simultaneously assess the effect of a series of covariates, which may vary over time, on the hazard (or conditional probability) of separation among women living in a stepfamily (see Blossfeld et al. 2007). The duration of the stepfamily episode at separation is established by subtracting the age at beginning of union from the age of women at separation or divorce, whichever came first. Stepfamily episodes that were still ongoing at the time of the survey or that ended with the death of the partner are censored, using the age of women at survey or at widowhood.

Fixed covariates - The first fixed covariate identifies the composition of the stepfamily, based on the existing relationships between the family members at the beginning of the episode. Three categories are distinguished: 1) stepmother families that comprise children living with their biological father and a stepmother; 2) stepfather families that include children living with their biological mother and a stepfather; and 3) stepmother/stepfather families that comprise two sets of siblings, i.e. a mother living with her own biological children and a father with his own children. The stepfather category is further broken down according to whether the woman experienced a stepfamily episode following the birth of children outside a union or following a conjugal separation.

The age of both partners of the couple at the beginning of the episode is introduced as a continuous variable, and all other covariates as dummy variables. The age of the youngest child present identifies three groups: preschool (0-4) years; elementary school (5-11) years; adolescence (12-20) years. The number of children present at the beginning of the episode is coded in three categories: ( 1 child; 2 children; 3 children or more). The highest educational level completed by respondents at survey is coded into four categories: 1) less than high school degree; 2) high school diploma; 3) college degree; and 4) university de-

6 For less than half of the stepmother family episodes, the woman reported that she started living with her partner shortly before her stepchildren joined her household (the median duration that separates the two events is 1.9 years). For the sake of coherence with the residential approach of stepparenthood imposed by the data, we used the arrival date of the stepchildren in the woman's household as the beginning of the stepfamily episode.

7 This approach that distinguishes the family episodes by rank is the most common in the literature. It is based on the idea that past experience influences subsequent behaviour and that the process underlying the first stepfamily episode might differ from that of ulterior episodes.

8 We were interested in studying the risk of union disruption among stepfamilies with dependent children. Although 18 is the legal age to define adulthood in Canada, we chose 21 as the age to mark this passage, given that children often pursue schooling, stay at home or depend on their parents for financial support until that age (Mitchell 2006). 
gree. A region variable distinguishes Quebec respondents from those living elsewhere in Canada. Respondents' mother tongue aims to control whether regional differences are due to cultural traits separating Francophone and Anglophone Canadians; it is coded into four categories: 1) English only; 2) French only; 3) both English and French; 4) any other languages. Finally, respondents are distinguished according to their religious affiliation (Protestant; Catholic; another religion (e.g. Islam or Jewish); no religion).

Time-varying covariates - Four time-varying covariates are included into the analyses. The first one indicates the presence of a common child from the moment that a first child is born to the couple. The second specifies the type of union, which can change from common-law union to marriage if the partners marry during the course of the episode. A third variable, which controls for the time period during which the stepfamily episode was experienced, is coded into the following four categories: 1) before 1970;2) 1970-1979; 3) 1980-1989 and 4) 1990 and after. Finally, the last time-varying covariate indicates the employment status of the respondent during the stepfamily episode; it is coded into three categories: 1) never worked; 2) working; and 3) not working (for those who had previously worked). For example, the value of the employment status of respondents can change from working, to not working, to working again, as a respondent who was employed at the beginning of the episode, stops working and then returns into employment during the course of the episode. Unfortunately, no information on other socioeconomic characteristics, such as income, was collected retrospectively in the survey and cannot be added to our analysis. Interaction variables combining, first, the type of union and region and, second, the type of union and period in which the episode was experienced are included in two separate models in order to test whether the effect of the union type varied across regions and periods. After excluding all cases in which the information on one or several covariates is missing, the final sample used in the regression models comprises 1,325 female respondents who experienced at least one stepfamily episode. ${ }^{9}$

Sample weights are used to adjust for the stratified and clustered design of the survey in the descriptive statistics. We further use the bootstrap weights provided by Statistics Canada in the Cox models in order to obtain unbiased and accurate estimates of variance. The results presented below reflect the standard errors derived from resampling each model 200 times.

\section{Results}

\section{Descriptive statistics}

The descriptive statistics for the covariates used in the analysis are presented in Table 1. The large majority (83\%) of stepfamily episodes experienced by women comprise a mother living with her own children and a partner who is not the father of these children $(24.2 \%+58.7 \%$; see the bottom line of Table 1$)$. This is not surprising given that women are more likely to live on a regular basis with their children following separation. Ap-

9 The sample in the models including the work status covariate comprises only 1,244 women; 81 cases with missing data on the work history had to be excluded. 
proximately $70 \%{ }^{10}$ of these stepfather families were formed following a union disruption, and $30 \%$ after the birth of children outside a union.

The majority (57\%) of women were cohabiting at the beginning of the stepfamily episode, but the percentage significantly varies across the different types of family. In stepfather families, mothers who did not previously live in a union are less likely to cohabit $(38 \%)$ than those who did so $(68 \%)$. The former are on average younger (25.3 years) and live with younger partners ( 28.5 years) than women who entered stepfamily life following a union dissolution (33,0 years for the women and 35,3 years for their partners). Women who lived in a stepfamily after giving birth outside a union have, on average, a smaller number of children (1.4), and their youngest child is younger (4.1 years) than in any other type of family. By definition, the number of children present is larger (3.0) in stepfather/stepmother families in which both partners live with children born from a prior relationship. Over $40 \%$ of women started their first stepfamily episode in the $1990 \mathrm{~s}$, and $28 \%$ did so in the previous decade. Compared to all women who experienced stepfamily life, the share of those who formed a union after giving birth outside a union continuously decreased across periods, in favour of stepmother families and of the stepfather families formed after a union dissolution. For example, the proportion of stepfather families following a birth outside a union was almost twice as high as that observed for all stepfamilies formed before 1970 (24.3\% versus $13.0 \%)$, whereas the proportion of those following a union disruption was nearly two times smaller (7.9\% versus $13.0 \%$ ); from 1990 onward, the situation had reversed, with the former being proportionally smaller, and the latter being relatively larger, than the percentage observed among all stepfamilies (respectively $30.5 \%$ and $47.2 \%$ compared to $42.9 \%$ ). In Quebec, stepfather families following a separation appear to be relatively more frequent than they are elsewhere in Canada, where stepfather families following a birth outside a union are more common.

Women living in stepmother families have achieved the highest level of education. Close to two-thirds of these women had completed a college or university degree, as opposed to less than $40 \%$ of mothers who had not previously lived in a union. Compared to the latter, they were also more likely to be working at the beginning of the stepfamily episode, in a proportion $(72 \%)$ close to that of mothers who had gone through a separation (69\%). Finally, among stepfather families formed following a union dissolution, we find a significantly smaller proportion of women who reported another language than only French or English as their mother tongue.

Table 2 gives the proportions of the stepfamily episodes that were still ongoing at various durations according to the composition of the family, based on life table estimates. Episodes that were still ongoing at the time of the survey, as well as those that were terminated by the death of the partner or the departure from the household of the last stepchild were censored, and only separation was considered as causing the end of the episode. Ten years after they began, a third of the first stepfamily episodes experienced by women had led to separation or divorce. Regardless of whether the woman had a previous union or not, stepfather families appear to be the most likely to break up. Less than twothirds of these families were still together ten years after the beginning of the episode, compared to over $85 \%$ of the families comprising a stepmother.

10 That is, $58.7 \%$ out of $82.9 \%$. 
Table 1: Descriptive statistics (\% or means) ${ }^{1}$ for covariates used in the analysis of separation among first stepfamilies episodes, according to family composition

\begin{tabular}{|c|c|c|c|c|c|}
\hline & Stepmother & $\begin{array}{l}\text { Familiy cor } \\
\text { Stepfather, mother } \\
\text { no union before }\end{array}$ & $\begin{array}{l}\text { mpositions } \\
\text { Stepfather, mother } \\
\text { union before }\end{array}$ & $\begin{array}{l}\text { Stepfather and } \\
\text { stepmother }\end{array}$ & All stepfamilies \\
\hline \multicolumn{6}{|l|}{ Type of union ${ }^{2}\left(x^{2}=90.8 p=.000\right)$} \\
\hline Marriage & 52.2 & 61.7 & 32.0 & 49.0 & 42.6 \\
\hline Cohabiting union & 47.8 & 38.3 & 68.0 & 51.0 & 57.4 \\
\hline \multicolumn{6}{|c|}{ Age at beginning of the episode, woman $\left(x^{2}=281.9 \mathrm{p} 0.000\right)$} \\
\hline Less than 25 years & 34.1 & 63.1 & 14.5 & 16.3 & 29.0 \\
\hline $29-29$ years & 21.8 & 16.9 & 22.3 & 32.7 & 21.3 \\
\hline $30-39$ years & 32.4 & 14.7 & 44.7 & 36.7 & 35.5 \\
\hline 40 years and older & 11.7 & 5.3 & 18.5 & 14.3 & 14.3 \\
\hline Mean age (mother) & 29.6 & 25.3 & 33.0 & 31.9 & 30.6 \\
\hline \multicolumn{6}{|c|}{ Age at beginning of the episode, man $\left(x^{2}=179.3 p 0.000\right)$} \\
\hline Less than 30 years & 24.0 & 70.0 & 32.3 & 12.2 & 39.5 \\
\hline $30-39$ years & 49.2 & 20.9 & 39.3 & 55.1 & 36.8 \\
\hline 40 years and older & 26.8 & 9.1 & 28.4 & 32.7 & 23.7 \\
\hline Mean age (father) & 35.3 & 28.5 & 35.3 & 37.2 & 33.7 \\
\hline \multicolumn{6}{|c|}{ Number of children in household $\left(x^{2}=195.0 \mathrm{p} 0.000^{*}=\right.$ no cases $)$} \\
\hline 1 & 57.5 & 76.6 & 45.3 & * & 52.8 \\
\hline 2 & 27.9 & 16.3 & 39.0 & 36.7 & 32.1 \\
\hline 3 and more & 14.5 & 7.2 & 15.7 & 63.3 & 15.1 \\
\hline Average number of children & 1.6 & 1.4 & 1.8 & 3.0 & 1.7 \\
\hline \multicolumn{6}{|c|}{ Age of youngest child in household $\left(x^{2}=106.1 \mathrm{p} 0.000\right)$} \\
\hline younger than 5 & 38.2 & 67.8 & 35.8 & 44.0 & 44.5 \\
\hline $5-11$ years & 41.6 & 26.9 & 43.0 & 44.0 & 38.8 \\
\hline 12 and older & 20.2 & 5.3 & 21.2 & 12.0 & 16.7 \\
\hline Average age of youngest child & 7.3 & 4.1 & 7.7 & 6.2 & 6.7 \\
\hline \multicolumn{6}{|c|}{ Proportion (\%) of women who gave birth or adopted $\left(x^{2}=75.1 \mathrm{p} 0.000\right)$} \\
\hline a child during the episode & 43.8 & 53.8 & 27.2 & 32.7 & 36.0 \\
\hline \multicolumn{6}{|c|}{ Period of beginning of the episode ${ }^{2}\left(x^{2}=79.1 p 0.000\right)$} \\
\hline Before 1970 & 13.4 & 24.3 & 7.9 & & 13.0 \\
\hline 1970-1979 & 13.4 & 20.9 & 16.2 & 18.4 & \\
\hline 1980-1989 & 29.1 & 24.3 & 28.7 & 30.6 & 27.8 \\
\hline 1990 and after & 44.1 & 30.5 & 47.2 & 51.0 & 42.9 \\
\hline \multicolumn{6}{|l|}{ Region $\left(x^{2}=19.9 p 0.000\right)$} \\
\hline Quebec & 23.6 & 16.9 & 29.2 & 18.4 & 25.1 \\
\hline Elsewhere in Canada & 86.4 & 83.1 & 70.8 & 81.6 & 74.9 \\
\hline \multicolumn{6}{|l|}{ Education $\left(x^{2}=68.4\right.$ p 0.000$)$} \\
\hline Less than high school & 15.2 & 40.3 & 24.1 & 26.0 & 26.9 \\
\hline High scholl diploma & 22.5 & 21.6 & 28.4 & 28.0 & 26.0 \\
\hline College degree & 40.4 & 31.9 & 37.2 & 30.0 & 36.1 \\
\hline University degree & 21.9 & 6.3 & 10.3 & 16.0 & 11.1 \\
\hline \multicolumn{6}{|c|}{ Work status $^{2}(\mathbf{N}=1244$ missing cases 81$)\left(x^{2}=106.1\right.$ p 0.000$)$} \\
\hline Never worked & 11.8 & 32.5 & 12.1 & 12.2 & 17.0 \\
\hline Not working & 9.6 & 10.3 & 11.8 & 20.4 & 11.5 \\
\hline Working & 72.5 & 51.3 & 69.2 & 63.3 & 65.1 \\
\hline Missing data & 6.2 & 5.9 & 6.9 & 4.1 & 6.5 \\
\hline \multicolumn{6}{|l|}{ Mother tongue $\left(x^{2}=15.3 p 0.000\right)$} \\
\hline English only & 60.7 & 67.9 & 63.3 & 63.3 & 64.1 \\
\hline French only & 23.0 & 19.9 & 27.7 & 28.6 & 25.2 \\
\hline $\begin{array}{l}\text { English and French } \\
\text { Other }\end{array}$ & 16.3 & 12.1 & 9.0 & 8.2 & \\
\hline \multicolumn{6}{|c|}{ Religion $\left(x^{2}=19.7\right.$ p $0.02 *=$ no cases $)$} \\
\hline Protestant & 32.6 & 44.1 & 36.6 & 38.8 & 37.9 \\
\hline Catholic & 46.1 & 39.7 & 43.4 & 46.9 & 43.0 \\
\hline Other & 7.3 & 3.4 & 2.8 & * & 3.5 \\
\hline None & 14.0 & 12.8 & 17.2 & 14.3 & 15.6 \\
\hline $\bar{N}$ & 164 & 359 & 756 & 46 & 1325 \\
\hline$\%$ & 13.5 & 24.2 & 58.7 & 3.7 & 100.0 \\
\hline
\end{tabular}

1 Percentage and means based on weighted data. The percentages sum up vertically.

2 Value taken at the beginning of the episode for time-varying covariates.

Source: Statistics Canada, 2001, General Social Survey (Cycle 15) on Family. 
Table 2: $\quad$ Life tables estimates of the proportion of first stepfamily episodes ongoing at various durations, according to family composition

\begin{tabular}{|c|c|c|c|c|c|}
\hline \multirow[b]{2}{*}{$\begin{array}{l}\text { Years since beginning } \\
\text { of the episode }\end{array}$} & \multirow[b]{2}{*}{ Stepmother } & \multicolumn{2}{|c|}{ Familiy composition } & \multirow[b]{2}{*}{$\begin{array}{l}\text { Stepfacher and } \\
\text { stepmother }\end{array}$} & \multirow[b]{2}{*}{ All stepfamilies } \\
\hline & & $\begin{array}{l}\text { Stepfather, } \\
\text { mother no } \\
\text { union before }\end{array}$ & $\begin{array}{l}\text { Stepfather, } \\
\text { mother union } \\
\text { before }\end{array}$ & & \\
\hline 1 & .98 & .92 & .96 & .99 & .95 \\
\hline 3 & .97 & .84 & .86 & .95 & .87 \\
\hline 5 & .92 & .75 & .79 & .92 & .80 \\
\hline 10 & .88 & .60 & .64 & .91 & .67 \\
\hline
\end{tabular}

Source: Statistics Canada, 2001 General Social Survey (cycle 15) on Family.

\section{Factors associated with stepfamily instability}

Results of the proportional hazards models, which aim to test our hypotheses, are presented in Table 3. The first model includes solely the demographic covariates; the education and cultural covariates are added in Model 2, and the work status covariate, for which a substantial number of cases the information is missing, in Model 3. For each model, separate equations are further run to test whether the effect of union type differs between regions or has changed across periods. The coefficients are presented in exponential form (risk ratios). A coefficient greater than 1 indicates that the covariate introduced in the model increases the risk (or conditional probability) of experiencing a separation; conversely, a coefficient smaller than 1 indicates that it decreases this risk. For categorical variables, the risk ratios need to be interpreted in relation to the reference category (omitted from the equation), which is assigned the value of 1 . The effect of variables, which values for a given woman may change over the course of the episode, is interpreted in the same way as the effect of fixed independent variables.

A separate analysis first showed that stepmother families are found to experience a lower risk of separation than stepfather families, as was hypothesized (results not presented). They have $66 \%$ less chances to separate than all stepfather families grouped into one category, even after all covariates are included in the equation, which indicates that the effect of the family type is not mainly due to differences in the socio-demographic composition of the two groups. ${ }^{11}$ Stepfamilies mixing two sets of siblings also face a low risk of break-up that is nearly $60 \%$ lower than that experienced by families formed around mothers living with their own children. This effect remains significant throughout all

11 We ran similar models to all those presented in Table 3, which combined into one single category all stepfather families, i.e. those formed following a birth outside a union as well as those formed after a union dissolution. The risk ratios attached to the type of family obtained in the basic models 1-3 are shown below. The detailed results of these analyses are available from the authors upon request.

\begin{tabular}{l|l|l|l}
\hline Variables & Model 1 & Model 2 & Model 3 \\
\hline Type of family (stepfather) & & & \\
Stepmother & $0.34^{* * *}$ & $0.34^{* * *}$ & $0.32^{* * *}$ \\
Stepfather and stepmother & $0.41^{*}$ & $0.41^{*}$ & $0.37^{*}$ \\
\hline
\end{tabular}


models and suggests that, in spite of its complexity, this type of stepfamily is a particularly stable stepfamily arrangement.

Table 3 presents the effect of the stepfamily composition on the risk of separation when distinguishing the type of event that led to the formation of stepfather families. The results run counter to our second hypothesis, which predicted the stepfather families in which mothers never lived in a union to be less likely to experience a separation than those who saw their prior union break up. The stepfather families formed after the birth of children outside a union have a $47 \%$ higher risk of breaking up than those following the disruption of a previous union (the reference category). The effect is statistically significant, even after controlling for the fact that mothers who gave birth outside a union were younger at the beginning of the stepfamily episode, and thus faced a higher risk of separation (see Model 1). The inclusion in Models 2 and 3 of all the other covariates does not significantly affect either the size of the coefficients attached to the family type, which remain large and significant.

As hypothesized, stepfamily couples who are cohabiting are found to be more unstable than those who are married. They exhibit a risk of separation that is $29 \%$ larger than that of married couples (Model 1). The negative impact of the type of union persists, even after taking into account the period during which the stepfamily episode was experienced and the fact that cohabiting unions are more frequent in recent periods that are characterized by high levels of conjugal instability.

Not surprisingly, the period in which the stepfamily episode took place does exert an important effect on the risk of conjugal disruption. The more recently the stepfamily was formed, the more likely couples were to separate. Hence, the results of the analysis presented in Table 3 show that couples living in a stepfamily before 1970 had a $60 \%$ lower risk to see their union break up than those who experienced life in this type of family during the 1970s, whereas those who did so after 1990 had nearly three times more chances to separate (see Model 1). Women living in Quebec were found to be $20 \%$ more likely to experience a union dissolution than their counterparts living in the rest of Canada; however, the result is not significant, even at the 0.10 level.

We expected the birth of a common child to stepfamily couples to substantially decrease the likelihood of parental separation, by creating a genetic link between all members of the family. The analysis shows that the arrival of a child does indeed reduce by approximately $20 \%$ the risk of separation of stepfamily couples, but the effect was found to be no longer statistically significant once we controlled for the type of the union and the period during which the stepfamily episode was experienced.

Model 1 also controls for the age of the partners and the age group and number of children present at the beginning of the episode, variables that probably all influence the decision of the stepfamily couple to have a child together. The analysis shows that the older the woman is at entry into the stepfamily episode, the less likely she is to undergo separation. Each additional year of age reduces by $4 \%$ the risk of family break-up. The effect remains significant throughout all models, and is in line with that observed in previous studies. The age of the male partner does not, however, appear to significantly influence the risk of union disruption, nor does the number of children present at the beginning of the family episode. Contrary to the results obtained in a previous study using Canadian data (Desrosiers et al. 1995), the age of the children present at the beginning of the step- 
family was not found to be statistically linked to the risk of separation, and stepfamilies with younger children did not appear to be less likely to break up than those comprising adolescents. ${ }^{12}$

Table 3: Effects of various covariates on the risk of women's first stepfamily episode to end by separation (risk ratios from Cox models) ${ }^{1}$

\begin{tabular}{|c|c|c|c|c|c|c|c|c|c|}
\hline \multirow[t]{2}{*}{ Variables $^{2}$} & \multicolumn{3}{|c|}{$\begin{array}{c}\text { Model with demographic } \\
\text { covariates }\end{array}$} & \multicolumn{3}{|c|}{$\begin{array}{c}\text { Model with all covariates } \\
\text { except for work status }\end{array}$} & \multicolumn{3}{|c|}{$\begin{array}{l}\text { Complete model with } \\
\text { all covariates }\end{array}$} \\
\hline & Model 1 & Model 1a & Model 1b & Model 2 & Model 2a & Model $2 b$ & Model 3 & Model 3a & Model 3b \\
\hline \multicolumn{10}{|c|}{ Type of family (stepfather, mother union before) } \\
\hline $\begin{array}{l}\text { Stepmother } \\
\text { Stepfather, mother } \\
\text { no union before } \\
\text { Stepfather and stepmother }\end{array}$ & $\begin{array}{l}0.40^{\star \star *} \\
1.47^{\star \star} \\
0.44^{*}\end{array}$ & $\begin{array}{l}0.39^{\star \star \star} \\
1.50^{\star \star} \\
0.44^{*}\end{array}$ & $\begin{array}{l}0.40^{* * *} \\
1.48^{* *} \\
0.44^{*}\end{array}$ & $\begin{array}{l}0.39^{* * *} \\
1.43^{*}\end{array}$ & $\begin{array}{l}0.38^{* * *} \\
1.45^{*}\end{array}$ & $\begin{array}{l}0.39^{* * *} \\
1.43^{*}\end{array}$ & $\begin{array}{l}0.36^{* * *} \\
1.41^{*}\end{array}$ & $\begin{array}{l}0.36^{* * *} \\
1.43^{*}\end{array}$ & $\begin{array}{l}0.36^{* * *} \\
1.41^{*}\end{array}$ \\
\hline \multicolumn{10}{|l|}{ Common child (no) } \\
\hline Yes & 0.82 & 0.82 & 0.82 & 0.83 & 0.83 & 0.83 & 0.85 & 0.85 & 0.85 \\
\hline Age of woman & $0.96^{*}$ & $0.97^{*}$ & $0.96^{*}$ & $0.97^{*}$ & $0.97^{*}$ & $0.97^{*}$ & $0.96^{\star *}$ & $0.96^{\star *}$ & $0.96^{\star *}$ \\
\hline Age of man & 1.00 & 1.00 & 1.00 & 0.99 & 0.99 & 0.99 & 1.00 & 1.00 & 1.00 \\
\hline \multicolumn{10}{|c|}{ Age of youngest child ( $0-4$ years) } \\
\hline $\begin{array}{l}5-11 \text { years } \\
12 \text { years and older }\end{array}$ & $\begin{array}{l}0.82 \\
0.94 \\
\end{array}$ & $\begin{array}{l}0.82 \\
0.94 \\
\end{array}$ & $\begin{array}{l}0.82 \\
0.94 \\
\end{array}$ & $\begin{array}{l}0.83 \\
0.99 \\
\end{array}$ & $\begin{array}{l}0.83 \\
0.99 \\
\end{array}$ & $\begin{array}{l}0.83 \\
0.99 \\
\end{array}$ & $\begin{array}{l}0.90 \\
1.15 \\
\end{array}$ & $\begin{array}{l}0.90 \\
1.15 \\
\end{array}$ & $\begin{array}{l}0.90 \\
1.15 \\
\end{array}$ \\
\hline \multicolumn{10}{|l|}{ Number of children (1) } \\
\hline 2 & 1.00 & 1.01 & 1.00 & 0.97 & 0.98 & 0.97 & 0.98 & 0.99 & .98 \\
\hline 3 and more & 0.86 & 0.86 & 0.86 & 0.86 & 0.87 & 0.86 & 0.88 & 0.89 & .88 \\
\hline
\end{tabular}

Type of union (marriage)

\begin{tabular}{|c|c|c|c|c|c|c|}
\hline Cohabitation & $1.29^{\dagger}$ & & $1.29^{\dagger}$ & & $1.36^{*}$ & \\
\hline Period (1970-1979) & & & & & & \\
\hline Before 1970 & $0.38^{* *}$ & $0.38^{* *}$ & $0.40^{* *}$ & $0.40^{* *}$ & $0.39^{\star *}$ & $0.39^{* *}$ \\
\hline 1980-1989 & $1.48^{\dagger}$ & $1.48^{*}$ & $1.41^{\dagger}$ & $1.42^{\dagger}$ & 1.35 & 1.36 \\
\hline 1990 and after & $2.78^{* * *}$ & $2.78^{*}$ & $2.68^{* * *}$ & $2.67^{* * *}$ & $2.56^{\star \star *}$ & $2.56^{\star * *}$ \\
\hline
\end{tabular}

Region (Elsewhere in Canada)

\begin{tabular}{|c|c|c|c|c|c|c|c|c|}
\hline \multicolumn{9}{|c|}{ Region (EIsewnere in canada) } \\
\hline Quebec & 1.20 & 1.20 & 1.11 & 1.25 & 1.11 & 1.20 & & 1.21 \\
\hline \multicolumn{9}{|c|}{ Type of union * Region (Canada * marriage) } \\
\hline Canada * cohabitation & 1.22 & & & 1.23 & & & 1.28 & \\
\hline Quebec * marriage & 1.05 & & & 0.98 & & & 1.06 & \\
\hline Quebec * cohabitation & $1.59^{*}$ & & & 1.48 & & & $1.69^{*}$ & \\
\hline \multicolumn{9}{|c|}{ Type of union * Period (1970-1979 * marriage) } \\
\hline$<1970$ * marriage & & $0.36^{\star *}$ & & & $0.37^{\star *}$ & & & $0.37^{* *}$ \\
\hline$<1970 *$ cohabitation & & 0.83 & & & 0.78 & & & 0.75 \\
\hline $1970-1979$ * marriage & & 1 & & & 1 & & & 1 \\
\hline $1970-1979$ * cohabitation & & 1.19 & & & 1.17 & & & 1.31 \\
\hline $1980-1989$ * marriage & & 1.46 & & & 1.39 & & & 1.38 \\
\hline $1980-1989$ * cohabitation & & $1.83^{*}$ & & & $1.76^{*}$ & & & 1.74 \\
\hline 1990 \& over * marriage & & $2.72^{\star \star *}$ & & & $2.60^{* * *}$ & & & $2.50^{* * *}$ \\
\hline 1990 \& over * cohabitation & & $3.54^{* * *}$ & & & $3.41^{* * *}$ & & & $3.48^{* * *}$ \\
\hline
\end{tabular}

12 We tried grouping children's age in various ways (e.g. creating smaller and larger age groups) but this did not change any of the results observed (results not shown). 


\begin{tabular}{|c|c|c|c|c|c|c|c|}
\hline \multirow[t]{2}{*}{ Variables $^{2}$} & $\begin{array}{l}\text { Model with demographic } \\
\text { covariates }\end{array}$ & \multicolumn{3}{|c|}{$\begin{array}{l}\text { Model with all covariates } \\
\text { except for work status }\end{array}$} & \multicolumn{3}{|c|}{\begin{tabular}{|c|}
$\begin{array}{c}\text { Complete model with } \\
\text { all covariates }\end{array}$ \\
\end{tabular}} \\
\hline & Model 1 Model 1a Model 1b & Model 2 & Model 2 & Model 2b & Model 3 & Model 3a & Model 3b \\
\hline \multicolumn{8}{|l|}{ Mother tongue (English) } \\
\hline French & & 1.03 & 1.03 & 1.03 & 0.98 & 0.97 & 0.98 \\
\hline English and French & & 1.01 & 0.99 & 0.99 & 1.09 & 1.06 & 1.07 \\
\hline Other & & 0.89 & 0.88 & 0.89 & 1.03 & 1.03 & 1.03 \\
\hline \multicolumn{8}{|l|}{ Religion (Protestant) } \\
\hline Catholic & & 1.16 & 1.16 & 1.16 & 1.10 & 1.11 & 1.10 \\
\hline Other & & 1.51 & 1.53 & 1.51 & 1.58 & 1.60 & 1.58 \\
\hline No religion & & 1.13 & 1.14 & 1.13 & 1.11 & 1.11 & 1.10 \\
\hline \multicolumn{8}{|c|}{ Education (High school diploma) } \\
\hline Less than high school & & 1.16 & 1.16 & 1.15 & 1.23 & 1.23 & 1.22 \\
\hline College degree & & 1.26 & 1.26 & 1.26 & $1.29^{\dagger}$ & $1.29^{\dagger}$ & $1.29^{\dagger}$ \\
\hline University degree & & 1.22 & 1.21 & 1.22 & 1.30 & 1.27 & 1.30 \\
\hline \multicolumn{8}{|l|}{ Work status (never worked) } \\
\hline Working & & & & & 0.95 & 0.96 & 0.95 \\
\hline Not working & & & & & 1.06 & 1.06 & 1.06 \\
\hline Log Likelihood & 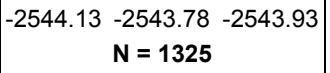 & -2540.82 & $\begin{array}{l}-2540.5 \\
\mathbf{N}=132\end{array}$ & -2540.67 & -2398.94 & $\begin{array}{l}-2398.61 \\
N=1244\end{array}$ & -2398.79 \\
\hline
\end{tabular}

${ }^{1}$ Level of significance: $* * *: \mathrm{p}<.001 * *: \mathrm{p}<.01 *: \mathrm{p}<.05+: \mathrm{p}<.10$ after applying bootstrap weights.

${ }^{2}$ The reference category is indicated in parentheses. Variables in italics are time-varying covariates.

Source: Statistics Canada, 2001 General Social Survey (cycle 15) on Family.

Models 2 and 3 further include socioeconomic and cultural covariates in the equation. The coefficients of some of these variables are relatively quite large, such as the one attached to religion other than Catholicism and Protestantism. However, neither the women's religion, nor their mother tongue appear significantly linked to the risk of stepfamily breakup, once other covariates are already included in the equation. Women who had obtained a college or university degree have a 20 to $25 \%$ higher risk to experience separation than those who just completed high school, but the difference does not at first appear to be statistically significant. Only once the presence of women in the labour market is controlled for, does the effect of having achieved a college degree become significant at the 0.10 level. The work status of women during the course of the stepfamily episode does not, however, appear in itself to have a substantial impact on its outcome.

For each of the three main models, two separate equations were run to test whether the effect that the union type exerts on the risk of separation varied between regions and across periods. Model 1a first shows that the risk of stepfamily married couples to separate does not vary whether they lived in Quebec or in the other Canadian provinces (risk of 1.05 compared to 1). The risk of separation of cohabiting couples does not either appear to be statistically different between regions (the test of the difference between the two coefficients did not turn out to be significant). However, Quebec cohabiting couples face a $60 \%$ higher risk of seeing their stepfamily break up than married couples living outside of this province. Our hypothesis stating that the difference separating Quebec cohabiting and married stepfamily couples would be narrower than that found elsewhere in Canada is thus not verified. Although non-significant, the gap observed in Quebec is in fact larger 
than that observed outside the province ( 1.59 versus 1.05 in the former, compared to 1.22 versus 1 in the latter). The size of the coefficients slightly varies when other covariates are included in the equation, but the conclusion remains the same (see models $2 \mathrm{a}$ and $3 \mathrm{a}$ ).

The next model aims to test whether the differential effect of marriage and cohabitation on stepfamily instability has changed across periods, and more specifically whether the negative impact of cohabitation relative to that of marriage has diminished over time. Model $1 \mathrm{~b}$ first clearly shows that the risk of separation of stepfamily couples has increased in a continuous fashion across periods for married as well as cohabiting couples. Compared to married women who lived in a stepfamily during the 1970s (the reference group), married women who did so prior to 1970 had a $64 \%$ lower risk to go through separation, whereas those who went through a similar experience during the 1990s had 2.7 times more chances to separate. Similarly, cohabiting women who lived in a stepfamily during the 1980s and the 1990s had respectively more than twice (coefficient of 1.83 compared to 0.83 ) and more than four times (3.54 versus 0.83 ) the chances to see their stepfamily break up than those who lived in a stepfamily before $1970 .{ }^{13}$ The gap separating the risk ratios of married and cohabiting couples has narrowed down substantially between the stepfamily episodes experienced before 1970 and those lived during the 1970s. Before 1970, cohabiting couples had over twice the risk of separating than married couples (coefficient of 0.83 versus 0.36 ), but only between 1.19 to 1.30 times this risk thereafter. However, in none of the periods used in the analysis is the difference separating married and cohabiting couples statistically significant. Therefore, we cannot conclude, as hypothesized, that the negative impact of cohabitation in relation to marriage on the duration of stepfamily has substantially diminished over time.

\section{Summary and Conclusion}

The aim of this paper was to analyze stepfamily instability in Canada using the information collected in the 2001 General Social Survey on Family and, more specifically, to examine the effect that the family composition and the type of conjugal union exerts on the risk of separation. On one hand, we wanted to test whether the composition of the family still exerts a determinant impact on its duration, given the increasing diversity of stepfamilies and the, at times, contradictory findings obtained in demographic and socio-psychological research. On the other hand, we wanted to ascertain to what extent the effect of the union type had changed over time, as cohabiting unions became more widespread and socially acceptable, and differed between the province of Quebec and the other Canadian provinces, where it had reached different levels of development. For this, we applied the proportional hazards model to the analysis of the first stepfamily episodes experienced by women.

Confirming our first hypothesis, the analysis showed that stepmother families experience a lower risk of separation than stepfather families. As argued in past research, this result can perhaps be explained by women's willingness to invest into their relationships

13 Though quite large, the gap separating cohabiting women who lived in a stepfamily before 1970 and during the 1970s is not statistically significant, but that observed between pre-1970 and 1990s families and that between the 1980s and 1990s families is. 
with stepchildren and the fact that fathers who reside with their own children are likely to be passably involved in child rearing and in family life more generally. Stepmother/stepfather families that mixed two sets of siblings were also found to be less likely to separate than those comprising only the mother's children, and this in spite of the complexity of the family structure. Although these families involve a larger number of members who share different family histories, the two partners living together are both acting as parent and stepparent of the children present, and this reciprocity might facilitate communication and reduce the possibility of conflict in the couple

The analysis did not, however, confirm our second hypothesis related to stepfamily composition. Hence, mothers who experienced stepfamily life after giving birth outside a union were found to be more - rather than less - likely to separate than those who did so following a union dissolution, even after we controlled for the age of mother and children, and women's achieved level of education and work status. This result is perhaps in part attributable to unmeasured characteristics, such as income or the lower commitment to conjugal life of women who started their family life outside of a union.

Our third hypothesis, predicting stepfamily couples living in a cohabiting union to be less stable that those who are married, was supported by the analysis. Not surprisingly, the risk of separation among stepfamily couples was shown to increase through more recent periods, for married as well as cohabiting partners. However, the negative impact of cohabitation in relation to marriage was not found as, expected, to diminish over time, as cohabitation became more widespread, nor did we observe the difference separating married and cohabiting couples to be narrower in Quebec, given the preponderance of this type of union among stepfamily couples. The fact that common-law unions are much more prevalent in Quebec than they are elsewhere in Canada does not appear to be conducive of greater conjugal stability, as we expected. Hence, the deinstitutionalization of conjugal life that has gone further in Quebec than in the other provinces seems to go hand in hand with rising aspirations of self-fulfilment and the willingness not to stay in unhappy relationships. Our results thus suggest that, as more flexible and easily revocable relationships gain in importance, all types of unions generally become more unstable, at least for stepfamily couples.

Other than these covariates, only the age of woman at the beginning of the stepfamily episode was shown to consistently affect the risk of conjugal separation at the conventional level of statistical significance $(p<.05)$. The older the woman was at her entry in stepfamily life, the lower her risk to see her family break up was. The birth of a child through the course of the episode was shown to reduce the risk of union dissolution, but not in a statistically significant manner.

Stepfamilies bring together individuals, of whom one partner at least has previously experienced family life and brings one or more children into the conjugal union. At the same time that they start living together, the partners either have to establish new relationships with stepchildren or to redefine their relations with their own children in the presence of a stepparent. The dynamics of the family life are obviously influenced by the characteristics of the two partners at the formation of the stepfamily, but also by the past trajectories that both of them had followed. Retrospective surveys, like the 2001 GSS that we used here, are quite successful for collecting the past histories of respondents through series of events that can be easily remembered and dated, such as births or marriages, and they provide rapidly and, at relatively lost cost, valuable data to study the evolution of family dynamics across 
cohorts and over time. However, their format prevents the collection of the life histories of the respondents' previous partners, and they are poorly equipped to gather information about situations that changed progressively over time, such as the proportion of time that children spend in each of their separated parents' household while growing up.

The retrospective nature of the survey we used perhaps partly explains some of our findings. The fact that stepmother families appeared more stable than stepfather families could be linked to the way in which the parental histories of respondents were collected. Hence, to be considered as experiencing a stepfather family episode, a mother just needed to report living with a partner who was not the father of her children before these definitely left her household, no matter how much time her children spent in her home and the degree of involvement of her partner in her children's lives. In contrast, to be counted as a stepmother, a woman had to mention having raised and lived with her partners' children, thus, to have played an active stepparent role and for a sufficiently long period to mention it later in a survey. Non-resident stepmothers who were found in psychological studies to have a more negative perception of their parental role because of their lack of contact on a regular basis with their partner's children were thus likely to be de facto excluded from our analysis. This selectivity problem perhaps accounts for the rather surprising result we obtained, like past demographic studies, in light of the evidence provided in psychological research on the difficulties faced by stepmothers in their relations with children. Further research is obviously needed to re-examine the issues of stepfamily definitions in retrospective surveys and of their effects on the duration of the family. A possible avenue to achieve such a goal might be to compare, in a given country, the results derived from two different sources of data, such as panel and retrospective surveys. In the absence of a prospective survey, an alternative approach could be to confront the results derived from separate samples of male and female respondents, who experienced stepfamily life either as parents or stepparents, regarding the effect of family composition on their risk to undergo separation. This is the task that we aim to pursue in our next research.

\section{Acknowledgments}

This paper builds on Valerie Martin's (2008) Ph.D. dissertation, "Stepfamilies in Canada: Numbers, characteristics, stability and childbearing". Support for this research was provided by the Social Sciences and Humanities Research Council of Canada, the McGill Canada Research Chair on Social Statistics and Family Change and the German Academic Exchange Service (DAAD). The authors thank Paul-Marie Huot for his assistance with data construction and analysis. The results presented are based on analyses conducted in the Centre interuniversitaire québécois de statistiques sociales/Quebec InterUniversity Centre for Social Statistics (CIQSS/QICSS) which provides researchers access to the micro-detailed data collected by Statistics Canada. The opinions expressed here do not represent the view of Statistics Canada. 


\section{References}

Ambert, A. M. (1986). Being a stepparent: Live-in and visiting stepchildren. Journal of Marriage and the Family, 48, pp. 795-804.

Beck, U. \& Beck-Gernsheim, E. (2002). Individualization. London: Sage Publications.

Blossfeld, H-P., Golsch, K. S. \& Rohwer, G. (2007). Event History Analysis with STATA. Mahwah, NJ, London: Erlbaum.

Booth, A. \& Edwards, J. N. (1992). Starting over: Why remarriages are more unstable. Journal of Family Issues, 13, pp. 179-194.

Buber, I. \& Prskawetz, A. (2000). Fertility in second unions in Austria: Findings from the Austrian FFS. Demographic Research, 3, pp. 1-44.

Bumpass, L. L. \& Lu, H. H. (2000). Trends in cohabitation and implications for children's family contexts in the United States. Population Studies, 54, pp. 29-41.

Bumpass, L. L., Raley, K. R. \& Sweet, J. A. (1995). The changing character of stepfamilies: Implications of cohabitation and nonmarital childbearing. Demography, 32, pp. 425-436.

Cherlin, A. (2004). The deinstitutionalization of American marriage. Journal of Marriage and Family, 66 , pp. 848-861.

Cherlin, A. (1978). Remarriage as an incomplete institution. American Journal of Sociology, 84, pp. 634-650.

Cherlin, A. \& Furstenberg, F. F. (1994). Stepfamilies in the United States: A reconsideration. Annual review of Sociology, 20, pp. 359-381.

Clarke, S. C. \& Wilson, B. F. (1994). The relative stability of remarriages - A cohort approach using vital statistics. Family Relations, 43, pp. 305-310.

Coleman, M., Ganong, L. \& Fine, M. (2000). Reinvestigating remarriage: Another decade of progress. Journal of Marriage and Family, 62, pp. 1288-1307.

Desrosiers, H., Le Bourdais, C. \& Laplante, B. (1995). Les dissolutions d'union dans les familles recomposées: l'expérience des femmes canadiennes. Recherches sociographiques, XXXVI, pp. 47-64.

Ermisch, J. F. \& Wright, R. E. (1991). The duration of lone parenthood in Great Britain. European Journal of Population, 7, pp. 129-158.

Fine, M. A. (1995). The clarity and content of stepparent role: A review of literature. Journal of Divorce and Remarriage, 24, pp. 19-34.

Giddens, A. (1992). The transformation of intimacy. Sexuality, love and eroticism in modern societies. Stanford, CA: Stanford University Press.

Griffith, J. D., Koo, H. P. \& Suchindran, C. M. (1985). Childbearing and family in remarriage. Demography, 22, pp. 73-88.

Hall, D. R. \& Zhao, J. Z. (1995). Cohabitation and divorce in Canada: Testing the selectivity hypothesis. Journal of Marriage and the Family, 57, pp. 421-427.

Henz, U. \& Thomson, E. (2005). Union stability and stepfamily fertility in Austria, Finland, France \& West Germany. European Journal of Population, 21, pp. 3-29.

Hetherington, M. E. (1993). An overview of the Virginia Longitudinal Study of Divorce and Remarriage with a Focus on Early Adolescence. Journal of Family Psychology, 7, pp. 39-56.

Ihinger-Tallman, M. (1988). Research on stepfamilies. Annual Review of Sociology, 14, pp. 25-48.

Ihingher-Tallman, M. \& Pasley, K. (1997). Stepfamilies in 1984 and today - A scholarly perspective. Marriage \& Family Review, 26, pp. 19-40.

Juby, H. \& Le Bourdais, C. (1999). Where have all the children gone? Comparing mothers' and fathers' declarations in retrospective surveys. Canadian Studies in Population, 26, pp. 1-20.

Juby, H., Le Bourdais, C. \& Marcil-Gratton, N. (2005a). Sharing roles, sharing custody? Couples' characteristics and children's living arrangements at separation, Journal of Marriage and Family, 67, pp. 157-172.

Juby, H., Marcil-Gratton, N. \& Le Bourdais, C. (2005b). When parents separate: Further findings from the National Longitudinal Survey of Children and Youth. Ottawa: Department of Justice Canada. 
Juby, H., Marcil-Gratton, N. \& Le Bourdais, C. (2001). A step further in family life: The emergence of the blended family. In Bélanger, A. (Ed.). Report on the demographic situation in Canada 2000. Ottawa: Statistics Canada (Catalogue nr. 91-209), pp. 169-203.

Kiernan, K. (2002). Cohabitation in Western Europe: Trends, issues, and implications. In: Booth, A. \& Crouter, A. C. (Eds.), Just living together. Mahwah, N.J.: Lawrence Erlbaum Associates: 3-31.

Lapierre-Adamcyk, É. \& Le Bourdais, C. (coll. Martin, V. \& Huot, P. M.). (2008). La diversification de la structure et de la composition des familles au Canada. Ottawa: Human Resources and Social Development Canada (Final report).

Le Bourdais, C. \& Juby, H. (2002). The impact of cohabitation on the family life course in contemporary North America: Insights from across the border. In: Booth, A. \& Crouter, A.C. (Eds.), Just living together. Mahwah, N.J.: Lawrence Erlbaum Associates, pp. 107-118.

Le Bourdais, C. \& Lapierre-Adamcyk, É. (coll. Pacaut, P.) (2004). Changes in conjugal life in Canada Is cohabitation progressively replacing marriage? Journal of Marriage and Family, 66, pp. 929-942.

Manning, W. D. \& Lamb, K. A. (2003). Adolescent well-being in cohabiting, married, and single-parent families. Journal of Marriage and Family, 65, pp. 876-893.

Martin, V. (2008). Stepfamilies in Canada: Numbers, characteristics, stability and childbearing. Montreal: McGill University, Department of Sociology (Ph. D. thesis).

Martin, V. \& Le Bourdais, C. (2008) Stepfamilies in Canada and Germany, a comparison. In: Bien, W. \& Marbach, J. H. (Eds.), Familiale Beziehungen, Familienalltag und soziale Netzwerke [Family relations, everyday life within families, and social networks]. Wiesbaden: VS Verlag für Sozialwissenschaften, pp. 241-278.

McLanahan, S., Garfinkel, I., Reichman, N., Teitler, J., Carlson, M. \& Audigier, C. N. (2003). The Fragile Families and Child Wellbeing Study baseline national report, Princeton, N.J.: Center for Research on Child Wellbeing, Princeton University.

Mitchell, B. A. (2006). The boomerang age: Transitions to adulthood in families. New Brunswick, N.J.: Aldine Transaction.

Pasley, B. K. \& Ihingher-Tallmann, M. (1987). Remarriage and stepparenting. Current research and theory. New York: Guilford Press.

Pasley, B. K. \& Moorefield, B. S. (2004). Stepfamilies. Changes and challenges. In: Coleman, M. \& Ganong, L. H. (Eds.), The handbook of contemporary families. Considering the past, contemplating the future. Thousand Oaks, CA: Sage Publications, pp. 317-330.

Prskawetz, A., Vikat, A., Philipov, D. \& Engelhardt, H. (2002). Pathways to stepfamily formation in Europe: Results from the FFS. Rostock: Max Planck Institute for Demographic Research (Working paper WP 2002-046.8), pp. 107-149.

Rendall, M. S., Clarke, L., Peters, H. E., Ranjit, N. \& Verropolou, G. (1999). Incomplete reporting of men's fertility in the United States and Great Britain: A research note. Demography, 36, pp. 135-144.

Statistics Canada. (2002a) (Ed.). Changing conjugal life in Canada. Ottawa: Statistics Canada (Catalogue nr. 89-576-XIE).

Statistics Canada. (2002b) (Ed.). Profile of Canadian families and households: Diversification continues. Ottawa: Statistics Canada (Catalogue nr. 96F0030XIE2001003).

Statistics Canada. (2001). General Social Survey, Cycle 15: The family. Ottawa: Statistics Canada (Public use microdata file documentation and user's guide).

Stewart, S. D. (2007). Brave new stepfamilies. In Stewart, S. (ed.). Brave new stepfamilies. Diverse paths toward stepfamily living. Thousand Oaks, CA: Sage Publications, pp. 1-23.

Stewart, S. D. (2001). Contemporary American stepparenthood: Integrating cohabiting and non-resident parents. Population Research and Policy Review, 20, pp. 345-364.

Sweeney, M. M. (2010). Remarriage and stepfamilies: Strategic sites for family scholarship in the $21^{\text {st }}$ century. Journal of Marriage and Family, 72, pp. 667-684.

Teachman, J. D. (2008). Complex life course patterns and the risk of divorce in second marriages. Journal of Marriage and Family, 70, pp. 294-305.

Teachman, J. D. (1986). First and second marital dissolution: A decomposition exercise for Whites and Blacks. The Sociological Quarterly, 27, pp. 571-590. 
Thomson, E. (2004). Step-families and childbearing desires in Europe. Demographic Research, 3, pp. 116-134.

Van de Kaa, D. J. (1987). Europe's second demographic transition. Population Bulletin, 42, pp. 1-59.

Weaver, S. E. \& Coleman, M. (2010). Caught in the middle: Mothers in stepfamilies. Journal of Social and Personal Relationships, 27, pp. 305-326.

White, L. K. \& Booth, A. (1985). The quality and stability of remarriages: The role of stepchildren. American Sociological Review, 50, pp. 689-698.

Wineberg, H. (1992). Childbearing and dissolution of the second marriage. Journal of Marriage and the Family, 54, pp. 879-887.

Wu, Z. (2000). Cohabitation. An alternative form of family living. Don Mills, Ont.: Oxford University Press.

Submitted on/Eingereicht am: 22.12.2010

Accepted on/Angenommen am: 11.04.2011

Addresses of the authors/Anschriften der Autorinnen:

Valerie Heintz-Martin, Ph.D.

Deutsches Jugendinstitut e.V. (DJI)

Nockherstraße 2

81541 München

Germany/Deutschland

E-Mail:heintz-martin@dji.de

Professor Céline Le Bourdais, Ph.D.

Canada Research Chair in Social Statistics and Family Change

Stephen Leacock Building, Room 713

855 Sherbrooke Street West

Montreal, Quebec

H3A 2T7

Canada/Kanada

E-Mail: celine.lebourdais@mcgill.ca

Évelyne Lapierre-Adamcyk, Professeure émérite

Université de Montréal, Département de démographie

Boîte postale 6128, Station Centre-ville

Montréal, Québec

H3C 2J7

Canada/Kanada

E-Mail: evelyne.lapierre-adamcyk@umontreal.ca 


\section{Appendix - Construction of stepfamily episodes and treatment of missing data}

The construction of stepfamily episodes led to a substantial reduction of the sample size, as summarized in Table A1. Of the original sample that comprised 13,646 female respondents, 2,372 were first excluded because they had never lived in a union by the time they were reached by the $2001 \mathrm{GSS}$. An additional number of 1,891 respondents were further eliminated, since they had never lived with any biological, adopted or step-children. In addition, 113 women, who had experienced only one union, but for which the date of the beginning was missing, were further excluded; the missing information made it impossible to ascertain whether the reported children were born within or outside the union, and consequently to decide whether the union was a biological two-parent family or a stepfamily. Slightly over half $(7,299)$ of the female respondents reported living only with biological (or adopted) children and doing so exclusively with the father of these children, regardless the number of childless unions that they might have experienced in the course of their life. Another 157 women with children for whom values on all variables were imputed by Statistics Canada, were further excluded from the analysis. ${ }^{14}$ Finally, 303 additional cases for which data were missing for central variables used to reconstruct the stepfamily episodes were eliminated. These cases comprised various combinations of missing values on the children's age at birth, at departure from the respondent's household and/or at the time of the interview and on conjugal unions. This exercise reduces the sample size from 13,646 to 1,511 female respondents who had experienced at least one stepfamily episode. ${ }^{15}$

Table A 1 - Construction of stepfamily episodes and exclusion of cases

\begin{tabular}{lr}
\hline & Number \\
\hline Initial sample & 13,646 \\
Exclusions: & 2,372 \\
$-\quad$ Never experienced a union & 1,891 \\
$-\quad$ At least one union, but never had any biological, adopted or step children & 113 \\
$-\quad$ Only one union and date of beginning is missing & 7,299 \\
$-\quad$ Only biological (or adopted) children and lived with the other parent of these children & 157 \\
$-\quad$ Only children with totally imputed data & 303 \\
\hline$\quad \quad$ vissing values on crucial variables (e.g., dates of beginning and end of a union re- & 12,135 \\
\hline Total number of excluded cases & 1,511
\end{tabular}

14 These children's age, sex and relationship to the respondent were all imputed by Statistics Canada, but the information on the age they had when leaving the respondent's household (or when joining it, for adopted or stepchildren), is missing.

15 A relatively high number (596) of respondents had missing data on one or more variables but could be kept in the analysis, because we were able to either impute data to these variables or censored the life history, by using other information available in the data file. For example, when the arrival date in the respondent's household of stepchildren still present at survey was missing, we assigned the date of the beginning of the union as that of the beginning of the stepfamily episode. 